\title{
Grupy etniczne, sprawcy i ofiary
}

\section{Steffen Hänschen}

„Kilka dni później Rosjanie wyzwolili Theresienstadt, ale również po ich przybyciu i zaopatrzeniu więźniów w najpotrzebniejsze rzeczy ludzie masowo umierali. Walczyłem ze śmiercią i nie przeżyłbym nawet ośmiu dni dłużej. Gdyby nie nadeszli Rosjanie, nie byłoby już potrzeby mówić o Hansie Frankenthalu" [Frankenthal 1999: 91].

Tymi słowami ocalały z Holokaustu Hans Frankenthal opisuje, jak przeżył koniec panowania nazistów w 1945 r. Nie tylko dla Hansa Frankenthala i więźniów obozów koncentracyjnych czy jeńców wojennych, ale także dla dużej części ludności z okupowanych przez Niemców krajów Europy Wschodniej żołnierze Armii Czerwonej przybyli jako wyzwoliciele. Dlatego też wielu witało ich tam z prawdziwym entuzjazmem. Inni - wśród nich podnosiły się także głosy nacjonalistów - wyrażali obawy, że oto doszła do władzy nowa dyktatura. Tereny, przez które radzieccy żołnierze maszerowali na Berlin, naziści zamienili w ciągu zaledwie kilku lat w krwawe pole bitwy. Ze społeczności żydowskiej tylko nieliczni mieli szczęście przeżyć chwilę wyzwolenia. Ci, którym się to udało, zawdzięczali swoje życie zwycięstwu Armii Czerwonej. Dobrze oddają to cytowane powyżej słowa Hansa Frankenthala.

Żadnego ludzkiego cierpienia nie można porównać z innym. Nie ma cierpienia większego czy mniejszego, a już z pewnością ocena indywidualnych doznań związanych z poczuciem przerażenia i sterroryzowania, jakie stało się udziałem ocalonych, nie należy do potomności.

Timothy Snyder, historyk z Uniwersytetu Yale, próbuje w książce Skrwawione ziemie znaleźć nowy punkt odniesienia, by ukazać powiązania pomiędzy morderczą polityką narodowych socjalistów a terrorem radzieckim [Snyder 2010a]. Koncentruje się - jak sugeruje tytuł - na krwawych działaniach obu dyktatur. Oba systemy są odpowiedzialne za masowe mordy i skrajnie represyjną politykę prowadzoną w tym samym czasie na tych samych obszarach. Ich ofiarą padły miliony ludzi. Jednak uwagę Snydera w mniejszym stopniu zaprząta cierpienie ofiar. Na plan pierwszy wysuwa pytanie, w jakim stopniu obydwa systemy wzajemnie na siebie oddziaływały, wspierały się i warunkowały. Decydującym elementem tego porównania jest pokrywanie się zasięgu ich władzy i wpływów na poszczególnych obszarach. Autor Skrwawionych ziem pisze, że represyjna polityka obu morderczych dyktatur - nakładając się na siebie - nie spowodowała w żadnym innym regionie Europy pierwszej połowy XX w. więcej mordów z powodów politycznych, niż właśnie tutaj, doprowadzając do około 14 milionów ofiar. 
Bloodlands - „skrwawione ziemie” - tym pojęciem określa Snyder obszar rozciągający się od wschodniej Polski, przez Białoruś, Ukrainę, kraje bałtyckie, aż po zachodnią Rosję. W okresie nie dłuższym niż lat trzydzieści mieszkańcy tej części Europy Wschodniej padli ofiarą politycznego ucisku dwóch totalitarnych państw, który pozostawił krwawy ślad wykraczający swoim zasięgiem ponad wszystko, co było znane do tej pory. Nigdzie indziej nie zginęło tak wielu ludzi w tak krótkim czasie, jak na Ukrainie i Białorusi podczas kolektywizacji rolnictwa oraz w okresie „wielkiego terroru” (,wielkiej czystki”) w latach 1937-1938, potem w latach 1939-1941 - kiedy oba reżimy objęły swoimi działaniami Polskę, republiki bałtyckie i zachodnią Ukrainę, jak też podczas całej drugiej wojny światowej - gdy narodowi socjaliści zrealizowali swój monstrualny program eksterminacji ludności na „skrwawionych ziemiach”. Zbiorowe mordy, jak stwierdza autor, nie zaczęŁy się wraz z wkroczeniem sił zbrojnych Trzeciej Rzeszy do Polski w roku 1939, ale już w 1933 r., kiedy ofiarami zabójczej polityki kolektywizacji rolnictwa realizowanej przez Stalina na Ukrainie padło około trzech milionów osób.

Gdy Snyder porównuje działania stalinowców z nazistowską polityką zagłady, wyraźnie uwidacznia się różnica między punktem widzenia jego a Hansa Frankenthala. $O$ ile w wypadku tego ostatniego osobiste przeżycia i cierpienie wysuwają się na plan pierwszy, o tyle amerykański historyk przyjmuje rolę osoby opisującej i analizującej wydarzenia, która patrzy na nie z perspektywy dzielących go od nich sześćdziesięciu lat. Snyder może porównywać działania nazistów i stalinowców, ponieważ - nieobciążony doświadczeniem ofiar - analizuje punkt widzenia ich mocodawców.

Tytułowy termin Bloodlands wywołuje - pewnie nieprzypadkowo - skojarzenie z angielskim terminem Borderlands, czyli „pogranicze”. Historycznie chodzi o wielokulturowy i wielojęzyczny region, którego odpowiednika można by długo szukać w innych częściach Europy. Przez wieki osiedlali się tutaj Żydzi, Ukraińcy, Łotysze, Bałtowie, Rosjanie, BiaŁorusini, Niemcy i przedstawiciele innych nacji. To były polskie Kresy, żydowska Strefa osiedlenia (Čerta osedlosti), czy niemieckie Prusy Wschodnie (Oßtpreusen). Druga wojna światowa przyniosła kres kulturowej różnorodności, a ziemie te poddano czystkom etnicznym - Żydów w większości wymordowano, inne grupy narodowe wypędzono lub przesiedlono. Wskutek tych działań kraje regionu mają zasadniczo jednolitą strukturę etniczną.

Timothy Snyder na „skrwawionych ziemiach” dostrzega przede wszystkim wyjątkowe nagromadzenie przemocy i zbrodni w krótkim okresie. Polityczna i społeczna specyfika „skrwawionych ziem”, która wynika z ich położenia i dziejów, była punktem wyjścia działania obu dyktatur, a czasem nawet torowała im drogę. To nie jest tylko kwestia historyczna: do czasów najnowszych charakterystyczne cechy regionu kształtują dyskusję i pamięć zbiorową o wydarzeniach z pierwszej połowy XX w. W złożonym spektrum rozmaitych doświadczeń interesy polityczne są często czynnikiem decydującym o kształcie pamięci, a zatem o tym, które wspomnienia uznać należy za ważne, a które za mniej istotne. 
Nie bez powodu wschodnioeuropejska debata o pamięci różni się pod wieloma względami od historycznej dyskusji trwającej w Niemczech w ostatnich dziesięcioleciach. Stanowisko niemieckie jest relatywnie jednoznaczne: oto ziemia sprawców. Nie podlega dyskusji, że w analizie dyktatury narodowych socjalistów priorytetowe znaczenie ma i powinno mieć określenie stosunku do sprawców i do ich ideologicznych przesłanek. Nie zawsze było to tak oczywiste, ale zawsze skutkowało specyficznym przebiegiem dyskusji, którą wieńczył wątek odpowiedzialności za zbrodnie.

W Niemczech Zachodnich po drugiej wojnie światowej problem ofiar narodowego socjalizmu stał się tematem tabu. Ich doświadczenia i rozmiar cierpień nie pojawiały się w publicznej debacie. Powoli, począwszy od lat osiemdziesiątych XX w., rozwijała się świadomość, jakie znaczenie mają wspomnienia pojedynczych ludzi, a ich przeżycia i doświadczenia zajmowały coraz większą przestrzeń w publicznej dyskusji. Ponadto, głównie za sprawą młodszego pokolenia, zaczęto zadawać pytania o sprawy, za które odpowiedzialność spoczywała na jego rodzicach. W ten sposób utorowano drogę do otwartego żądania relacji z czynów winowajców, a także stawienia czoła wspomnieniom ofiar narodowego socjalizmu.

$\mathrm{Na}$ „skrwawionych ziemiach” napotykamy na zdecydowanie bardziej skomplikowaną sytuację. Nie tylko dlatego, że przez wiele lat trwania realnego socjalizmu nie była możliwa żadna otwarta dyskusja na temat obu dyktatur. Zamiast tego heroizowano i jednostronnie przedstawiano działania Armii Czerwonej. Zagładę ludności żydowskiej traktowano jako część masowej eksterminacji obywateli Związku Radzieckiego, a antysemicką odsłonę rasizmu skrzętnie przemilczano.

Dodatkowych problemów nastręcza fakt, że często trudno jest wyznaczyć wyraźne linie podziału między sprawcami a ofiarami. Sprawcy z okresu „wielkiego terroru” w Związku Radzieckim byli niekiedy także ofiarami okupacji nazistów. Niektórzy pomagali Żydom, ukrywając ich z narażeniem życia, a zarazem wspierali nacjonalistyczne ugrupowania podziemne, które reprezentowały poglądy antysemickie i same dokonywały masowych mordów. Paradoks ten dotyczy na przykład członków Ukraińskiej Powstańczej Armii (UPA).

Złożone losy poszczególnych ludzi lub całych grup w państwach „postsowieckich” są do dziś często niezauważane. W ostatnich latach utrwala się tendencja do generalizowania aktów ucisku, podczas gdy cierpienia poszczególnych grup etnicznych stają się przedmiotem instrumentalizacji: służą jako ideologiczna podbudowa procesu kształtowania narodu.

Specyficznym charakterem poszczególnych „skrwawionych ziem” Snyder zajmuje się bardzo zdawkowo. Nie ma choćby w jego pracy żadnych odniesień do żydowskiej Strefy osiedlenia w zachodniej części dawnej carskiej Rosji. Tylko na marginesie wspomina przesłanki, z powodu których ideologia stalinowska na „skrwawionych ziemiach” miała 
szanse powodzenia, a miejscowa ludność przyjmowała żołnierzy Wehrmachtu po części z entuzjazmem. Poza tym ograniczenie analizy do obszaru „skrwawionych ziem” ma sens być może w odniesieniu do nazistowskiej polityki eksterminacji - nawet jeśli sam autor rozszerza jej strefę oddziaływania także na obszary Węgier czy Rumunii. Jednak politykę Związku Radzieckiego trudno zamknąć w geograficznych ramach tak pojmowanej Europy Wschodniej. Radziecki „wielki terror”, antysemityzm i masowe deportacje były fenomenem dotyczącym także terenów poza regionem „skrwawionych ziem”, choćby Kaukazu Północnego.

Mimo to Snyderowi udaje się w porywający i poruszający sposób opisać cierpienia „skrwawionych ziem”, doświadczanych przez blisko pół wieku tragizmem prowadzonej tam na szeroką skalę polityki zagłady. Autor książki rzuca światło na zbrodnie popełnione w czasie trwania reżimu stalinowskiego, co - jeśli się weźmie pod uwagę niepełne dziś jeszcze analizy tamtych wydarzeń - jest jego wielką zasługą. W ten sposób wypełnia poważną lukę historyczną w (zachodnio)niemieckim dyskursie. Dzięki niemu w polu niemieckiego widzenia znajdują się i groza sowieckiej dyktatury, i „wielki głód”, i strach, i terror, który siali stalinowcy. W dominującym dyskursie w Niemczech Zachodnich komuniści byli traktowani z dezaprobatą, mówiło się o nich tylko w słowach negatywnych. Okres zimnej wojny miał w tym swój udział. Dlatego na lewicy uznanie zyskała postawa sprzeciwu wobec oficjalnego potępienia każdego aspektu realnego socjalizmu. Żadna ze stron nie dokonała przy tym ani analizy zbrodni stalinowskich, ani rzetelnej krytyki stalinizmu.

\section{Stare wino w nowych buktakach?}

Jeszcze dziesięć lat temu porównanie dyktatury narodowych socjalistów z dyktaturą radziecką byłoby w Niemczech nie do pomyślenia. Spór historyków niemieckich po 1986 r. jednoznacznie zdyskredytował możliwość konfrontacji obu reżimów. Niemieccy historycy rozpoczęli wówczas dyskusję na temat relatywizacji niemieckiej zbrodni Holokaustu poprzez porównywanie ze sobą systemów: komunistycznego i narodowosocjalistycznego. W kolejnych latach zyskało na znaczeniu przekonanie, że wszelkie porównania z systemem nazistowskim i jego aparatem zbrodni wobec ludności żydowskiej powinno się od razu ucinać, natomiast wnikliwie badać przyczyny podejmowania takiego zabiegu. Porównanie stalinizmu i nazizmu postrzegano jako próbę negowania odpowiedzialności Niemców za zbrodnie hitlerowskie. W Niemczech Wschodnich próby te uważano od samego początku jako atak na państwo wschodnioniemieckie. Z tego samego powodu - odmowy relatywizacji zbrodni hitlerowskich - w Niemczech Zachodnich, głównie w środowiskach lewicowych, przymykano oczy na zbrodnie Stalina. 
Nie ulega kwestii, że zbrodnia ludobójstwa na ludności żydowskiej w Europie była czymś niespotykanym. Globalny charakter zbrodniczej polityki antysemickiej, zimna kalkulacja i przemysłowy charakter mordów dokonywanych na Żydach odróżnia nazistowską zbrodnię od innych masowych egzekucji tego okresu. Nie tylko skala mordu decyduje o jego wyjątkowości, ale również stopień nienawiści do ofiar oraz głębokie przekonanie o słuszności tego działania, jakie podzielali winowajcy i wszystkie osoby, które z nimi współdziałały, a dzięki którym dokonanie masowej zbrodni było w ogóle możliwe.

Z historycznego dystansu łatwiej jest ocenić wydarzenia i spojrzeć na nie z nowej perspektywy, bez doszukiwania się w każdej próbie porównania systemów zamiaru rewidowania historii. Spór niemieckich historyków należy już do przeszłości i nikt - poza skrajnie prawicowymi stronnictwami przeczącymi istnieniu Holokaustu - nie wątpi dziś, że nazistowska zagłada Żydów nie ma precedensu w historii. Jak trafnie zauważył Jörg Barberowski w recenzji książki Snydera: „Holokaust stał się tymczasem kryterium oceny zbrodniczej przestępczości zorganizowanej przez system państwa" [Barberowski 2011].

Rozliczenie z tragicznych wydarzeń okresu drugiej wojny światowej i procesu, który do niej doprowadził, może dopomóc w tym, by zapobiegać teraźniejszym i przyszłym zbrodniom ludobójstwa lub szybciej je powstrzymywać. Niemieckie doświadczenia z ostatnich lat pomagają zrozumieć, jakim błędem jest unikanie odpowiedzialności za przeszłość. W ramach zmierzającego do osądzenia sprawców, niewystarczającego rozliczenia, które przyszło stosunkowo późno, bo w latach sześćdziesiątych XX w. - po uprowadzeniu Adolfa Eichmanna z Argentyny do Izraela - nie zawsze dysponowano odpowiednimi instrumentami prawnymi, lub też nie potrafiono wykorzystać tych, które istniały.

\section{Marsz po trupach}

Polityka represji prowadzona przez Związek Radziecki i hitlerowskie Niemcy na „skrwawionych ziemiach" skierowana była przeciwko grupom etnicznym, stanowiącym mniejszość na danym terenie. Ich eliminacja miała stanowić zabezpieczenie własnej potęgi. Snyder próbuje iść w tym kierunku, podejmując się interpretacji wydarzeń historycznych, jakie rozegrały się na „skrwawionych ziemiach” na początku XX w. Pisze, że Adolf Hitler podjął decyzję o „ostatecznym rozwiązaniu kwestii żydowskiej” w przypływie złości i frustracji spowodowanych tym, iż wojna nie jest jeszcze wygrana. Cel - pokonanie Związku Radzieckiego w niespodziewanym ataku - okazał się nieosiągalny. Dopiero wtedy miał zadecydować, że przynajmniej poprzez eksterminację ludności żydowskiej zrealizuje jedno ze swoich zbrodniczych zamierzeń.

Wysuwając na pierwszy plan zimną kalkulację Hitlera i narodowych socjalistów, Snyder przesuwa na plan dalszy pobudki będące następstwem brutalnego antysemityzmu. Z książki wynika, że narodowym socjalistom chodziło w pierwszej kolejności o realizację pewnej - jakkolwiek wydawałoby się to nam dzisiaj przerażające i niedorzeczne - ogólnej koncepcji, a nie o wymordowanie Żydów. 
Podobnie autor pisze o polityce przymusowej kolektywizacji i bezwzględnej egzekucji kontyngentów, która prowadziła do tzw. wielkiego głodu w latach trzydziestych XX w. Postrzega ją jako odpowiedź Stalina na nieudaną próbę przeprowadzenia kolektywizacji rolnictwa. Także tutaj skupia uwagę na osobistych fantazjach osoby dzierżącej najwyższą władzę w Związku Radzieckim, która bała się utraty swojej pozycji.

Te próby obu mocarzy: Stalina i Hitlera, dążących do utrzymania władzy i zachowania systemu poprzez stosowanie krwawych represji, łączy - jak twierdzi autor książki - podobny sposób działanie obu dyktatur. „Tak więc jako tyrani Hitler i Stalin prowadzili podobną politykę: powodowali katastrofy, winili za nie wskazanych przez siebie wrogów, po czym wykorzystywali śmierć milionów, by dowieść, że ich działania były niezbędne lub pożądane. [...] Zarówno w przypadku kolektywizacji, jak i «ostatecznego rozwiązania» konieczna okazała się masowa ofiara, by odsunąć widmo rzeczy nie do pomyślenia - błędu przywódcy" [Snyder 2011: 418].

Motywy sprawców i ich ideologiczne tło znalazły się tym sposobem na drugim miejscu za interesami mocodawców, w imieniu których działali. Mocodawcy wykorzystali sprawców niczym bezwolne narzędzia, które wykonują polecenia powierzane im przez instytucje państwowe.

Ta perspektywa pomija aspekty, które odgrywają decydującą rolę w porównaniu obu systemów. Rasistowskie nastawienie niemieckich sprawców mordów prowadziło do kategoryzowania ludzi ze względu na ich pochodzenie, do sklasyfikowania ludności żydowskiej, do poniżania Żydów, a w końcu do wykluczenia ich ze społeczeństwa. Jednym z przykładów masowych zachowań było publiczne obcinanie brody prawowiernym Żydom. W ten sposób wystawiano ich na pośmiewisko. Obraz Żyda jako Untermenscha - „podczłowieka”, który musi zostać wyrugowany ze społeczności, utrwalił się w świadomości Niemców, stając się elementem służącym utrzymaniu władzy, spoiwem integrującym społeczeństwo narodowych socjalistów. Niemieccy sprawcy mordów pieczętowali własną wyższość poniżaniem ofiar.

Z punktu widzenia analizy ideologii stalinowscy sprawcy mordów nie mieli żadnego interesu, by udowadniać własną rasistowsko zdefiniowaną wyższość. Dla nich najważniejsze było zrealizowanie wyznaczonych celów, które jawiły im się jako konieczne kroki na drodze do uformowania wolnego społeczeństwa. Polityka służąca wywołaniu „wielkiego głodu" na Ukrainie przy zastosowaniu środków przymusu nakierowana była w pierwszej linii na szybkie wprowadzenie kolektywizacji rolnictwa i egzekucję powinności oddawania deputatów żywności. Ukraińcy stali się ofiarami nie z powodu swojej narodowej przynależności, lecz dlatego że Ukraina była spichlerzem Związku Radzieckiego. Tutaj produkowano większą część żywności dla całego kraju. Zgodnie z oficjalnymi wytycznymi polityki ZSRR mniejszości narodowych nie prześladowano tam z powodów rasowych. Odmienność obu reżimów w uzasadnieniu prześladowań grup etnicznych była przyczyną zasadniczych różnic $w$ ich postępowaniu. 
To z przyczyn wielkomocarstwowych - a nie rasowych - podejmował Związek Radziecki w czasie drugiej wojny światowej działania przeciw polskim dążeniom niepodległościowym, choć polski rząd emigracyjny w Londynie zaliczał oficjalnie do grona sprzymierzeńców. Wojskowa akcja „Burza”, w ramach której doszło ostatecznie do wybuchu powstania warszawskiego w 1944 r., była podjętą przez polski rząd emigracyjny i Armię Krajową próbą wyrzucenia Niemców z Polski i zdobycia w sensie politycznym mocniejszej pozycji wyjściowej w okresie powojennym. Związek Radziecki powstania nie wsparł. Żołnierzy walczących o niepodległość uważano za przedstawicieli reakcji, a bezpośrednio po zakończeniu działań wojennych i wyzwoleniu ziem polskich w latach 1944 i 1945 nowy rząd w Warszawie uznał ich za „wrogów ludu” i poddał represjom. Jako przykład antypolskiej postawy Moskwy Snyder podaje działania radzieckich oddziałów partyzanckich, które pod koniec wojny brały udział w akcjach przeciw Polakom. „W niektórych przypadkach sowieckich partyzantów wykorzystywano przeciw polskim bojownikom. Oddział Tewje Bielskiego wziął na przykład udział w rozbrajaniu jednostek Armii Krajowej" [Snyder 2011: 327].

Autor nie wspomina jednak, że oddział Bielskiego był żydowską grupą partyzancką, a AK - armią znaną z antysemityzmu. Żydzi byli przyjmowani w szeregi Armii Krajowej tylko w nielicznych wypadkach, a rozstrzelanie ludności żydowskiej przez jej jednostki nie były pojedynczymi zdarzeniami. Jak dalece działania oddziału Bielskiego były odpowiedzią na antysemickie zachowania poszczególnych grup bojowych AK - jest to kwestia nie do pominięcia w rozważaniach, jakie proponuje Snyder.

Nie podlega dyskusji, że Związek Radziecki traktował polskie dążenia niepodległościowe jako zagrożenie dla własnych interesów. Trzeba jednak podkreślić, że układ polityczny na „skrwawionych ziemiach” był zdecydowanie zbyt skomplikowany, by dało się go dopasować do dualistycznej koncepcji Snydera. Motywy miejscowej ludności, która brała udział w krwawych porachunkach, były niejednolite. Podejmując próbę wyjaśnienia wydarzeń historycznych tylko z pozycji walki o władzę ówczesnych supermocarstw, Snyder jest nieprecyzyjny, a jego tezy nie zawsze zgadzają się z faktami historycznymi. Na przykład ze szczegółowego omówienia tzw. akcji „Reinhard” wyciąga wniosek, że „[...] obiekty akcji «Reinhard» zamknięto ze względu na zbliżanie się Armii Czerwonej” [Snyder 2011: 301]. Jednak w tym czasie Niemcy deklarowali już dawno zakończenie akcji „Reinhard”. Dążenie do wpisania ciągu zdarzeń we własną koncepcję prowadzi autora do błedów faktograficznych.

Pozostaje pytanie, czy naziści wymordowaliby Żydów również wtedy, gdyby nie zostali przyhamowani podczas „wojny błyskawicznej” w Związku Radzieckim? Zbrodniczy antysemityzm był integralnym elementem ich ideologii, a spirala mordów dokonywanych na ludności żydowskiej nie rozpoczęła się dopiero po wejściu wojsk hitlerowskich do Związku Radzieckiego, lecz wraz z nim. Już od pierwszego dnia ataku na ZSRR niemieckie i litewskie jednostki bojowe eliminowały ludność żydowską na Litwie. W ciągu niespełna kilku dni akcja ta przybrała charakter systematycznej masowej eksterminacji. 
Teza, jakoby Hitler nie mogąc osiągnąć celów wojskowych, rozpoczął eksterminację Żydów, wydaje się dość problematyczna. Odpowiedzialnością za klęski na froncie wschodnim obarczył on w pierwszej linii swoich generałów, a nie „Żydów”. Poza tym także po 1942 r. w głowach niemieckich mocodawców nadal błąkała się nadzieja na zwycięstwo. Gdy w zachodniej części Związku Radzieckiego dokonywano masowych rozstrzeliwań, a działalność obozu zagłady Kulmhof (Chełmno nad Nerem) i akcja „Reinhard” nabierały tempa, funkcjonariusze nazistowskiego aparatu państwowego ciągle wierzyli w ostateczne zwycięstwo Trzeciej Rzeszy. Za niepowodzenia i opóźnienia w przebiegu działań wojennych nie winiono Żydów, lecz generałów Wehrmachtu.

W dyskursie na temat decyzji o tzw. ostatecznym rozwiązaniu kwestii żydowskiej większość historyków już dawno zdystansowała się od tezy, że był jeden moment inicjujący. Mówi się raczej o procesie, który - w sposób nieunikniony - zmierzał ku decyzji o wymordowania ludności żydowskiej w całej Europie. Dodatkowym impulsem ją przyspieszającym była nie tylko sytuacja na froncie wschodnim, jak argumentuje Snyder, choć, być może, doprowadziła ona do intensyfikacji mordowania Żydów. Także na Zachodzie naziści napotykali rosnące trudności. Stany Zjednoczone wypowiedziały Niemcom wojnę, skutkiem czego do Europy zaczęło napływać coraz więcej wojska zza oceanu. Reakcja Hitlera na rozszerzenie zasięgu działań wojennych mogła być dokładnie taka sama, jak reakcja na sytuację na froncie wschodnim - miał on obarczyć odpowiedzialnością za wojnę międzynarodowe żydostwo i chcieć, by zapłaciło za to najwyższą karę [Goebbels 2005: 498-499].

Jest też sporne, czy Snyder nie przecenia roli Hitlera i Stalina. Autor Skrwawionych ziem upatruje przyczyn ich zbrodniczych decyzji w obawie przed utratą przywództwa. Z pewnością pozycja lidera w zhierarchizowanych dyktaturach oraz niepowodzenie $w$ realizacji politycznych celów odgrywały wielką rolę, jednak nie można do tego sprowadzać przyczyn zbrodni takich, jak Holokaust. Snyder nie proponuje żadnego wyjaśnienia genezy „ostatecznego rozwiązania kwestii żydowskiej”. Zamiast tego koncentruje się na opisach krwawych działań dyktatury. W tym sensie nie udało mu się sprostać własnemu zadaniu porównania obu systemów. Udało mu się natomiast wykazać, że oba systemy popełniły podobne zbrodnie, że dokonały tego w tym samym miejscu, że podobne były ich sposoby postępowania oraz że ich działania zazębiały się i nawzajem pobudzały.

„Tak więc jako tyrani Hitler i Stalin prowadzili podobną politykę: powodowali katastrofy, winili za nie wskazanych przez siebie wrogów, po czym wykorzystywali śmierć milionów, by dowieść, że ich działanie były niezbędne lub pożądane. Każdy z nich miał swoją utopię transformacji, jak również grupę, którą obwiniano, gdy realizacja tej utopii okazywała się niemożliwa, a wreszcie politykę masowych mordów, które dało się ogłosić rodzajem zastępczego zwycięstwa" [Snyder 2011: 418].

Interakcja działań Trzeciej Rzeczy i Związku Radzieckiego zwiększała masowość mordów - ta teza to punkt ciężkości książki Snydera. Masowe mordy są tym, co połączyło Stalina z Hitlerem. W książce dominują liczby, porównania i wyliczenia, które tworzą 
jej poruszający styl. Przydaje on historii napięcia, ale jednocześnie dzięki niemu umyka wiele niezbędnych szczegółów, wkradają się błędy - jak choćby ten, że obozy zagłady włączone do akcji „Reinhard” nie zostały zamknięte w 1943, lecz w 1944 r. Tymczasem - i na tym polega problem - Skrwawione ziemie przetłumaczono na wiele języków jako dzieło popularnonaukowe. Książka jest szeroko cytowana i omawiana. Dziesięć czasopism w USA - m.in. „The Economist”, „The Financial Times”, „The Independent” - uznało ją na za książkę roku 2010. Wyróżnienie takie ma charakter referencji.

\section{Nacjonalizacja pamięci zbiorowej}

Zgadzam się ze Snyderem, że na „skrwawionych ziemiach” pamięć o drugiej wojnie światowej i polityce ucisku ZSRR została upolityczniona i była wykorzystywana do celów narodowych. Pamięci tej nie wolno tymczasem odrywać od historii masowych mordów. „Jedynie historia masowego zabijania może połączyć w jedno liczby ze wspomnieniami. Bez historii wspomnienia stają się prywatne, co oznacza dzisiaj - narodowe, a liczby stają się publiczne, czyli służą za instrument międzynarodowej rywalizacji o tytuł męczenników. Pamięć należy do mnie i mam prawo z nią robić, co zechcę; liczby są obiektywne i musisz zaakceptować moje wyliczenia niezależnie od tego, czy ci się podobają, czy nie. Takie rozumowanie daje nacjonaliście usprawiedliwienie, gdy atakuje bliźniego" [Snyder 2011: 433-434].

To prawda, że usytuowanie wspomnień w historycznych ramach jest konieczne i istotne. Problem w Europie Środkowo-Wschodniej nie polega jednak na tym, że wspomnienia te nie znalazły się w historycznym kontekście, lecz na tym, że debata wokół pamięci jest wybiórcza. Tworzy pamięć selektywną, służącą narracji budowania niepodległego narodu. W rezultacie rozmaite i niedające się ze sobą pogodzić wspomnienia rzadko stają się tematem publicznej debaty. Dla konstytuowania otwartej kultury pamięci byłoby pożądane, aby dopuścić do głosu wspomnienia prześladowanych mniejszości i pojedynczych ludzi, wsłuchać się w ich relacje, a rozmaitość wszelkich bolesnych doświadczeń i przeżyć potraktować z całą powagą.

Główną rolę odgrywa relacja między sprawcami a ofiarami oraz odpowiedzialność przyszłych pokoleń za ich czyny i cierpienie. Poprzestanie na zadenuncjowaniu jednoznacznych „zleceniodawców eksterminacji” - to działanie krótkowzroczne. Dlatego ważne jest, jak Timothy Snyder interpretuje rolę sprawców, jak ocenia wpływ ideologii na ich postępowanie. W książce Skrwawione ziemie nie chodzi o polityczną koncepcję obu dyktatur czy ich genezę, lecz głównie o zimną kalkulację władzy w tych reżimach. Autor reprezentuje przeciwne stanowisko wobec poglądów Daniela Goldhagena, który w swoich badaniach koncentruje się głównie na motywach sprawców zbrodni i w tym upatruje punktu zwrotnego dla tragicznych wydarzeń XX w. 
W recenzji książki Goldhagena Worse than war [Goldhagen 2004] Timothy Snyder pyta o znaczenie osobistego zaangażowania poszczególnych sprawców, któremu Goldhagen przypisuje decydującą rolę [Snyder 2010b]. Goldhagen definiuje sprawcę jako tego, kto świadomie i w wyraźny sposób przyczynia się do śmierci innego człowieka, realizując tym samym część polityki eliminacji. Snyder dystansuje się od takiego ujęcia tematu i słusznie zauważa, że - przykładowo - członkowie żydowskiej policji, którzy na rozkaz nazistów zapędzali ludzi do warszawskiego getta, nie działali z pewnością z pobudek o charakterze kryminalno-rasistowskim. Ich motywem była przede wszystkim chęć ochrony siebie i rodziny tak długo, jak to tylko możliwe. Nie można zatem zawsze zakładać dobrowolności, kiedy mowa o pobudkach poszczególnych aktorów odgrywających jakąś rolę w rasistowskiej polityce eksterminacji prowadzonej przez nazistów.

Sprawcy wprowadzali w czyn nakreślone przez dyktatury kierunki działania. To dawało im przywileje. Jak mało ma to wspólnego z ideologią, pokazuje kwestia kolaborantów, którzy najpierw wspierali system stalinowski, a potem - w takim samym zakresie - nazistowski. Snyder zastanawia się, jak to możliwe, że ci sami ludzie stawali do dyspozycji obu reżimów jako posłuszni pomocnicy. „Uważa się, że wielu ludzi, ze wszystkich grup [społecznych], pomagało $w$ jakiś sposób instytucjom obu okupantów - radzieckiego i niemieckiego. [...] Ci lokalni pomocnicy odgrywali ważną rolę w radzieckiej i niemieckiej polityce - najpierw w jednej, a potem w drugiej” [Snyder 2010b: 81]. Tych właśnie ludzi nazywa Snyder kolaborantami. Stanowiąc oparcie obu reżimów, unaoczniają, jego zdaniem, dwoistość polityki Związku Radzieckiego i nazistowskich Niemiec oraz dowodzą, jak mało znacząca była dla sprawców podbudowa ideologiczna. „Trudno pogodzić ich działania z wcześniejszym ideologicznym zaangażowaniem" - pisze Snyder w tym samym tekście.

Czy nie jest jednak możliwe, że u podłoża oportunistycznej postawy pojedynczych ludzi lub całych grup leżały właśnie pobudki ideologiczne? Zwraca uwagę, że Snyder prawie nie zajmuje się stosunkiem poszczególnych grup etnicznych do siebie. Tymczasem mowa o regionie, który ma własną historię antysemityzmu. Wiek XIX i początek XX były naznaczone antysemickimi incydentami, włącznie z pogromami. Narodowi socjaliści mogli szukać odniesienia do tych wydarzeń, podobnie zresztą jak do nowszej, represyjnej i morderczej polityki stalinowców. Ponieważ autor nie uwzględnia w książce tych kierunków rozwoju, nie udaje mu się wypracować całościowej historii regionu, która uwzględniałaby rolę wydarzeń poprzedzających radziecką dyktaturę w polityce eksterminacji narodowych socjalistów.

Również nie będzie zrozumiałe nastawienie wielu osób entuzjastycznie witających Wehrmacht na terenach Związku Radzieckiego, o ile nie weźmiemy pod uwagę poczynań stalinowskiej dyktatury. Narodowych socjalistów często traktowano jako wyzwolicieli spod komunistycznego ucisku, co po wdrożeniu bezprecedensowej polityki „wielkiego głodu" na Ukrainie nie powinno aż tak bardzo dziwić. Nierzadko radość z powodu wkroczenia Niemców była pozorna. Wielu zaangażowało się w ruch oporu przeciwko niemieckim 
okupantom na rzecz narodowej przyszłości. Pogromów towarzyszących wkroczeniu Wehrmachtu na zachodnią Ukrainę i Litwę, których ofiarą padło tysiące Żydów w 1941 r., nie da się wyjaśnić bez uwzględnienia różnych aspektów przeszłości tego regionu. Zaliczyć trzeba do nich wielowiekowy antysemityzm, społeczną separację, dopiero niedawno zakończoną politykę ucisku carskiej Rosji oraz represyjną politykę władz radzieckich w latach 1939-1941, kiedy na podstawie porozumienia z nazistowskimi Niemcami tereny te znalazły się w stalinowskiej strefie wpływów. To tylko kilka elementów tej historii.

Tłumaczenie: Barbara Grunwald-Hajdasz

\section{Bibliografia}

Barberowski Jörg, 2011, Hitler und Stalin. In verwüstetem Land, „Die Zeit”, nr 29 z 14 lipca 2011; www.zeit.de/2011/29/L-Snyder-Bloodlands (dostęp z 7 sierpnia 2012).

Browning Christopher, 1992, Ordinary Men: Reserve Police Battalion 101 and the Final Solution in Poland, New York : HarperCollins.

Frankenthal Hans, 1999, Verweigerte Rückkehr. Erfahrungen nach dem Judenmord, współpraca Andreas Plake, Babette Quinkert, Florian Schmaltz, Frankfurt/M.: Fischer Taschenbuch 1999 [Lebensbilder. Jüdische Zeugnisse und Erinnerungen].

Goebbels Joseph, 2005, Die Tagebücher von Joseph Goebbels, wyd. Elke Fröhlich, t. 2/2, München: Sauer.

Goldhagen Daniel Jonah, 1996, Hitler's Willing Executioners: Ordinary Germans and The Holocaust, New York: Alfred A. Knopf.

Goldhagen Daniel Jonah, 2004, Worse than War: Genocide, Eliminationism, and the Ongoing Assault on Humanity, New York: PublicAffairs.

Kailitz Steffen (red.), 2008, Die Gegenwart der Vergangenheit. Der „Historikerstreit“ und die deutsche Geschichtspolitik, Wiesbaden: Verlag für Sozialwissenschaften.

Leonhard Wolfgang, 1955, Die Revolution entläßt ihre Kinder, Köln: Kiepenheuer\&Witsch.

Snyder Timothy 2010a, Bloodlands. Europe between Hitler and Stalin, New York: Basic Books.

Snyder Timothy, 2010b, What We Need to Know about the Holocaust, „The New York Review of Books” z 9 grudnia 2010.

Snyder Timothy, 2011, Skrwawione ziemie. Europa między Hitlerem a Stalinem, tłum. Bartłomiej Pietrzyk, Warszawa: Świat Książki. 